\title{
Standard-bearers of Hussitism or Agents of Germanization?
}

\author{
Czech Jews and Protestants Competing and Cooperating for \\ the Religion of the Future, 1899-1918
}

\section{Introduction: Czech Jews and Protestants as Political Allies and Avant-garde of Czechness}

In 1932, the "Svaz Čechů-židů v Ceskoslovenské republice" (Union of Czech-Jews in the Czechoslovak Republic) published a small booklet on the history of its movement. The text opened with the common ground of Jews and Czechs in the Bohemian land: both were heirs of the Czech reformation, struggling against Catholic Habsburg rule and its attempts at Germanization. Even more than the Czechs, the author claimed, the Jews had to overcome German influences to find their place within the nation. In the end, he concluded, they succeeded, and the democratic and tolerant Czechoslovak republic exemplified this successful Czech-Jewish trajectory. It was strikingly obvious to the author that, although heavily referencing the Czech reformation as an overall concept of the national history, this path did not end in the emergence of a Protestant nation, but in an entirely new religious and national entity. ${ }^{1}$

In a similar vein, František Žilka (1871-1944), a prominent Czech Protestant clergyman, praised the republic's founding president, Tomáš Garrigue Masaryk (1850-1937), calling him the embodiment of the religious foundations of the Czechoslovak state. Guiding Žilka’s religious vision was "humanity," an idea at once Protestant and universal. ${ }^{2}$ Only by being religious in this way could a nation succeed. ${ }^{3}$

1 Dějiny českožidovského hnutí (Prague: Svaz Čechů-židů v Ceskoslovenské republice, 1932), $1-2$.

2 The Czech word used for humanity, "humanita" was a neologism, describing a humanitarian political concept.

3 František Žilka, "Masaryk a Protestantism," in Masarykův Sbornik. Časopis pro Studium Života a Díla T. G. Masaryka. Svazek čtvrtý: T. G. Masarykovi k šedesátým narozeninám. Redigovali Edvard Beneš, František Drtina, František Krejčí a Jan Herben, eds. Vasil K. Škrach and Druhé 
In the present article, I do not wish to dwell on the peculiarities of CzechJewish assimilation. ${ }^{4}$ Taking a different course, I seek to signal the strong parallels between the positions of two influential groups, one consisting of Czech Protestants and one of Czech Jews, when faced with the question of integration or assimilation into a Catholic or secular vision of society without repudiating one's religious and cultural identity. At the turn of the twentieth century, the two communities were similarly pressured to assimilate into mainstream society, and they formulated analogous answers to the question of their place in a future Czech nation. Thus, they were not only allies out of necessity in that they represented religious minorities in an overwhelmingly Catholic society; rather, they successfully shaped a progressive religious counter-narrative of the modern Czech nation, opposing the position that melded traditionalist religion with secular nationalism. ${ }^{5}$

Ultimately, Czech Protestants and Jews drew on a vision of religious progress that could incorporate different identities while remaining Czech in its essence. In doing so, they joined forces with other progressive activists. Given its size, this religious-political coalition was surprisingly successful in the 1907 Austrian election, the first under universal male suffrage. Moreover, it managed to critically shape the discourse of the new Czechoslovak republic in 1918.

\section{The Czech National Narrative in the $19^{\text {th }}$ Century}

The Czech national movement of the nineteenth century prided itself on being a large tent. Unlike other contemporary collective narratives, proponents of the Czech "national rebirth" did not tie their national identity to an existing religious

Vydání, Masarykův Sborník 4 (Prague: Čin, 1930): 106-19, here at 108-9. Of course, there is a multitude of similar sources between 1918 and 1938.

4 This had already been done in comprehensive fashion by several scholars. See Hillel Kieval, The Making of Czech Jewry: National Conflict and Jewish Society in Bohemia, 1870 - 1918 (Oxford and New York: Oxford University Press, 1988); Martin J. Wein, History of the Jews in the Bohemian Lands (Leiden and Boston: Brill, 2015); Michal Frankl, "Prag ist nunmehr antisemitisch": Tschechischer Antisemitismus am Ende des 19. Jahrhunderts, Studien zum Antisemitismus in Europa 1 (Berlin: Metropol, 2011); Kateřina Čapková, Czechs, Germans, Jews? National Identity and the Jews of Bohemia (Oxford and New York: Berghahn Books, 2012); for an earlier account, see also Martina Niedhammer, Nur eine "Geld-Emancipation”? Loyalitäten und Lebenswelten des Prager jüdischen Großbürgertums 1800 -1867, Religiöse Kulturen im Europa der Neuzeit 2 (Göttingen: Vandenhoeck \& Ruprecht, 2013).

5 To a certain extent, this was an attempt to incorporate the vision of the first Czech awakeners, from a century earlier, into modern society. 
denomination, but rather to a historical one. They managed to do so by pitting themselves against a decidedly Catholic monarchy and invoking a unique Czech tradition of religious tolerance, dating back to the Czech reformation and its martyr Jan Hus (c. 1370 -1415). At the same time, there remained an abiding tension between this vision of an historically tolerant nation and more exclusivist notions of the Hussite past, which could at times be virulently anticlerical and anti-Semitic. Still, until the late nineteenth century, nationalist ideology was restricted largely to the upper strata of society, making it a matter of a small elite.

Alongside the Czech language and the historical rights of the Bohemian estates, Hus and the community of Czech brethren, as well as the whole period of the Bohemian reformation through the battle of White Mountain, became symbols of the growing national consciousness. While the Czech national imagery - like many others - had a distinctly religious ring to it, it did not align with a single religious denomination. In the aftermath of the 1848 revolution, members of the reformed Church had seen themselves as the embodiment of a Protestant nation, but Lutherans stayed within a transnational framework up until $1900 .^{6}$ And although many of the fathers of the Czech national rebirth had indeed been Protestants of either the reformed or the Lutheran church, the bulk of the Czech-speaking population remained Catholic. ${ }^{7}$ The emerging nationalist framework of the late nineteenth century, therefore, was not that of a Protestant, but rather a non-Catholic (and non-German) nation. ${ }^{8}$ This allowed not only Czech-speaking Lutherans and reformed Protestants, but also Czech-speaking Jews, to portray themselves as part of the nation and to craft a singular spiritual

6 The Czech-speaking Lutheran community nationalized itself much later than the reformed church because the latter encompassed most of the Czech Protestants. It was also the reformed church several nationalist intellectuals converted to. Nonetheless, the notion of one existing national denomination never gained much traction. See Ondřej Matějka, “Čeští luteráni 1861-1918: od emancipace k unii,” in Luteráni v českých zemích v proměnách staletí, eds. Jiří Just, Zdeněk R. Nešpor, and Ondřej Matějka (Nakladatel: Lutherova Společnost, 2009), 219-309; Zdeněk R. Nešpor, "Evangelické církve," in Náboženství v 19. století: Nejcírkevnější století nebo období zrodu českého ateismu?, eds. Zdeněk R. Nešpor and a kol. (Prague: Scriptorium, 2010): 116-68. 7 Patrick Cabanel points out some interesting similarities to French nationalists of the time; see Patrick Cabanel, "Protestantism in the Czech Historical Narrative and Czech Nationalism of the Nineteenth Century,” National Identities 11:1 (2009): 31- 43.

8 Martin Schulze Wessel, "Die Konfessionalisierung der tschechischen Nation," in Nation und Religion in Europa: Mehrkonfessionelle Gesellschaften im 19. und 20. Jahrhundert, eds. HeinzGerhard Haupt and Dieter Langewiesche (Frankfurt am Main: Campus, 2004): 135-50. 
symbiosis under the banner of a rather vague and purposely ahistorical Hussite tradition. ${ }^{9}$

The liberal governments in the 1860s had provided legal security and emancipation to both Protestants and Jews in the Habsburg monarchy. ${ }^{10}$ Religious communities were strengthened and showed signs of what could be called 'confessionalization,' when attempting to unify (and nationalize) their services in churches and synagogues as well as establishing control over more outlying communities in the Bohemian lands. ${ }^{11}$ It was the situation in these smaller towns that might be said to have driven the changes within each community. This was particularly true for the Protestant and Jewish minorities, whose more progressive wings established themselves in towns like Kolin and Pardubice. In both Czech Protestant and Czech Jewish communities, this development originated within similar socio-cultural groups of intellectuals, whose vision was to integrate into the Czech mainstream national identity by retaining their own spiritual identity.

By the late nineteenth century, a modern society with all the signs of social differentiation and a mass public had begun to emerge in the region. Czech elites had long ago emancipated themselves from what they perceived as an effort to Germanize their culture within the Habsburg Empire. By the late 1880s, within an expanding public, a bourgeois liberal national party - Česká strana svobodmysl$n a$, referred to as the 'Young Czech Party' - started to dominate the national discourse as well as elections to the Vienna chamber of deputies. ${ }^{12}$ Jews and Protestants alike perceived their fate linked to that of liberal nationalism. This

9 Kateřina Čapková and Michal Frankl, "Diskussionen über die 'Judenfrage' in den böhmischen Ländern," in Die "Judenfrage” in Ostmitteleuropa: Historische Pfade und politisch-soziale Konstellationen, eds. Andreas Reinke et al., Studien zum Antisemitismus in Europa 8 (Berlin: Metropol, 2015): 183-247, here at 184-6.

10 Although the main Protestant churches were recognized by the Austrian state already in the late eighteenth century, it was the "Protestantenpatent" of 1861 which restricted the (renewed) legal influence of the Catholic church in religious matters for good.

11 The use of the term "confessionalization" in this context is rightfully disputed. For the sake of this argument, it should simply define attempts of intensified institutionalization and homogenization of religious communities. See Wolfgang Häusler, "Die österreichischen Juden zwischen Beharrung und Fortschritt," in Die Habsburgermonarchie 1848-1918, vol. IV: Die Konfessionen, eds. Adam Wandruszka and Peter Urbanitsch (Vienna: Verlag der Österreichischen Akademie der Wissenschaften, 1985): 633-69, here at 655; Zdeněk R. Nešpor, "Náboženské oživení v evangelických církvích ve druhé polovině 19. století,” in Christianizace českých zemí v středoevropské perspektivě, ed. Jiř̂́ Hanuš (Brno: Matice Moravská, 2011): 268 - 87.

12 See Bruce M. Garver, The Young Czech Party 1874-1901 and the Emergence of a Multi-Party System, Yale Historical Publications, Miscellany 111 (New Haven and London: Yale University Press, 1978), $190-8$. 
integrative nationalist consensus held until the late 1890s, despite the increasingly overt anti-Semitism and anticlericalism of an influential wing of the Young Czechs. ${ }^{13}$

By the turn of the century, the two Protestant churches found themselves in parallel positions. Although by and large they had nationalized themselves, they remained minority denominations. Moreover, advocating a Protestant nation placed Czech patriots uncomfortably close to pan-German nationalism and its attacks against the Catholic Habsburg monarchy. In response to this political climate, a group of younger clergymen, advocating an independent, unified, and politically active Czech Protestant church, became increasingly influential. In 1919, this unified "Evangelical Church of the Czech Brethren” (Českobratrská církev evangelická) became a reality. ${ }^{14}$

Amongst Jews in the Bohemian lands, a Czech-Jewish assimilationist movement appeared during the late 1870s. They likewise appealed to the national symbolism of the Czech nation and condemned anti-Semitism as a German, rather than Czech, trait. Within the Jewish communities, these "Czecho-Jews" called upon others to speak Czech and integrate into the Czech nation, whose historical character was one of tolerance. At the turn of the century, this movement could claim success in turning a growing number of Bohemian and Moravian Jews towards assimilation: the Czech language began to overtake German in virtually all rural and small-town Jewish communities, Prague as the largest city being something of an exception to this trend. According to this assimilationist movement, Jews were indebted to the Czech nation and should strive to be as Czech as possible. ${ }^{15}$

13 Already in 1873, shortly before his death, František Palacký (1798-1876), doyen of the Czech national movement, had to react to growing tensions in the national movement and stressed his Lutheran background against anticlerical attacks from Národní listy, the most influential newspaper of the national movement, which was accusing his denomination of illoyality; see Ondřej Matějka, “Čeští luteráni 1861-1918: od emancipace k unii,” in Just, Nešpor, and Matějka, eds., Luteráni v českých zemích v proměnách staletí, 219-309, here at 266.

14 Seeing as several leaders in both churches advocated a unified church long before, I will use the term "Protestant" in a rather indiscriminate way, when speaking of progressive Lutheran and Reformed Protestants alike.

15 Hillel Kieval, Languages of Community: The Jewish Experience in the Czech Lands (Berkeley, CA: University of California Press, 2000), 151-5; Iveta Vondrášková, “The Czech-Jewish Assimilation Movement and its Reflection of Czech National Traditions,” Judaica Bohemiae 36 (2000): $143-59$, here at $153-5$. 


\section{The National Consensus Falls Apart}

By the late 1890s, however, the fledgling mass public threatened to outstrip the liberal nationalists themselves. In the Bohemian lands, but also throughout the whole of Cisleithania, the liberal parties were thrown into crisis. Existing discourses on collective identity shattered.

The most visible change was the decline in influence of the Young Czech Party, which had won several landslide victories in elections between 1889 and 1891 and had become the undisputed representative of Czech bourgeois nationalism. Its proponents struggled to compete with the rising mass movements of the working class and rural political Catholicism, and the integrative narrative of an anti-Catholic nation started to lose traction. As the Czech public itself grew, so did the realization that most Czechs were, after all, Catholic. At the same time, German liberalism was supplanted by a growing and aggressive pan-German movement, thus making new forms of cooperation in the Vienna chamber of deputies a necessary political move for Czech liberals. ${ }^{16}$ The leadership of the Young Czech Club in Vienna had to navigate among Catholics, socialists and pan-Germans. Some concessions to Catholic parties were required, a consequence of the obstructionist politics of the German nationalists and the intransigence of the workers' movement. ${ }^{17}$ Beginning in 1891, the Young Czechs had to strike a balance between their integrative position as the dominant Czech party and their need to compromise with the government. This led to criticism of the party from both within and without, and weakened its grip on the Czech intellectual scene as the only option for political action. ${ }^{18}$

In 1897, the political landscape of Bohemia saw several new currents. Mostly originating in the Young Czech Party, these currents were appalled at the latter's compromise position vis-à-vis the monarchy. These "progressives" (pokrokárí), mostly young intellectuals from the small towns of Bohemia, never formed a singular party. Instead, they adhered to a common political framework that perceived politics as a general cultural activity beyond elections and parliament,

16 The anti-Semitic and anti-Habsburg "Alldeutschen" movement led by Georg Ritter von Schönerer (1842-1921) did exceptionally well amongst the Germans in Bohemia, winning a record of 21 seats in the 1901 elections. Although short-lived, its impact on the Czech political public should not be underestimated.

17 See Karel Kramář, Anmerkungen zur böhmischen Politik. Aus dem Böhmischen übersetzt von Josef Penízek (Vienna: Konegen, 1906), 24.

18 For a still relevant overview, see Otto Urban, Die tschechische Gesellschaft 1848-1918, Anton Gindely Reihe zur Geschichte der Donaumonarchie und Mitteleuropas 2 (Vienna, Cologne, and Weimar: Böhlau, 1994), 626-34. 
were sharply critical of the Catholic Church, and had a deep interest in the socalled social question. ${ }^{19}$

At the same time, the consensus on what defined Czech history (and therefore Czech identity) was becoming increasingly fragile. Starting with a debate on supposedly historical Czech manuscripts, which proved to be fabrications from the early nineteenth century, the intellectual public contested the historical meaning of the "Czech question." This sparked a discourse that lasted for decades. Basically, the issue boiled down to that of historical truth versus the historical meaning of the Czech nation. ${ }^{20}$ Embedded in this controversy was the question who belonged to this nation and who could enter it. ${ }^{21}$

The rural masses, who heretofore had been little more than objects of intellectual nationalist visions, started to enter the public sphere. As the nation grew, so did the pressure on minorities to assimilate. The rise of anti-Semitic movements across the monarchy was one reaction to the crisis of liberalism and political mass mobilization through a gradually expanding electorate. ${ }^{22}$ The anti-Semitism was furthered by the peculiar place Jews found themselves in several Bohemian and Moravian cities, where they could tip the electorate to either a German or a Czech majority. At one moment they might be viewed as coveted keys to local majorities, and at the next traitors to the national cause. ${ }^{23}$ The Czech nationalist movement, hoping to overcome Austrian-German supremacy, put pressure on Bohemian Jews to fall in line with the national cause

19 See Jan Havránek, "Počátky a kořeny pokrokového hnutí studentského na počátku devdesatých let 19. stoletî,” Acta Universitatis Carolinae - Historia Universitatis Carolinae Pragensis. Příspěvky k dějinám Univerzity Karlovy 2:1 (1961): 5-33; Karen J. Freeze, “The Progressive Youth of the 1890s: Children of the December Constitution,” in Bildungsgeschichte, Bevölkerungsgeschichte, Gesellschaftsgeschichte in den böhmischen Ländern und in Europa: Festschrift für Jan Havránek zum 60. Geburtstag, eds. Hans Lemberg et al., Schriftenreihe des österreichischen Ost- und Südosteuropa-Instituts 14 (Vienna: Verlag für Geschichte und Politik, 1988): $275-85$.

20 Miloš Havelka, “Spor o smysl českých dějin 1895-1938," in Spor o smysl českých dějin 18951938, ed. Miloš Havelka (Prague: Torst, 1995): 7-43, esp. 10-24.

21 Already during the 1850s self-styled Czech patriots had attacked Bohemian Jewish publicists like David Kuh (1819-1879) for casting doubt on the veracity of the manuscripts. See Kieval, Languages of Community, 92-3.

22 Pieter M. Judson, Exclusive Revolutionaries: Liberal Politics, Social Experience, and National Identity in the Austrian Empire, 1848-1914 (Ann Arbor, MI: University of Michigan Press, 1996), 223-25. The period of 1897-1907 was a transitional one, starting with the expansion of the census franchise and ending with the 1907 elections by universal male suffrage.

23 See Markéta Weiglová, "Jews as a Barometer of the National Struggle in Bohemia and Moravia, 1890 - 1910,” Judaica Bohemiae 43 (2007): 93-120, here at 106-8. 
and was quick to scapegoat them in case of political defeat. ${ }^{24}$ However, these demands allowed only for complete assimilation and neglected the possibility of a Czech-Jewish agency. While the Czech milieu did not see a full-blown racially charged anti-Semitism like the German-Austrian one, it did develop a more exclusive vision of Czechness. Whether the anti-Semitic undertones centered on political accusations of Jews as agents of Germanization or on popular Catholic stereotypes, the effect was the same: a growing number of Czech elites denied that Jews could be a part of the nation. Consequently, Czech anti-Semitism eventually did develop into a political force of its own. ${ }^{25}$ Moreover, several of the parties that emerged in the late 1890s were - like the National Social Party - quite willing to use anti-Semitic slogans as an electoral rallying cry. The rise of political Catholicism dealt another blow to the political influence of traditional liberal nationalism.

Protestants, of course, were in a much stronger position. Still, the quest for the meaning of Czech history started to reframe the narrative of "Hussites vs Catholics." A new generation of historians pointed to the importance of the Catholic phases in Czech history, claiming that one ought to affirm Czech history as a whole or refrain from claiming historical truths about the nation. ${ }^{26}$ This approach jeopardized the privileged position of Czech Protestants, who could argue for a Protestant interpretation of history more openly than Czech Jews, but nonetheless had to face a growing Catholic Czech nationalism.

\section{Convergence at the Turn of the Century, 1897-1904}

By 1897, some Czech Jews and Protestants had entered a converging trajectory with the progressive movement: they all resisted the emerging alliance between the Young Czech Party and the Catholic rural masses, and countered the vision of an agnostic, but practically Catholic, nation with that of a second Czech spiritual awakening, akin to the national rebirth in the first half of the nineteenth century. Yet, a true political alliance between these groups remained unlikely: Jewish assimilationists were aware of the anti-religious stance of most progres-

24 Hillel Kieval, "Nationalism and Antisemitism: The Czech-Jewish Response," in Living with Antisemitism: The Jewish Response in the Modern World, ed. Jehuda Reinharz (Hanover, N.H.: Brandeis University Press by University Press of New England, 1987): 210 -33, esp. 213-5. 25 Frankl, Prag ist antisemitisch, 16-7.

26 Miloš Havelka, “Spor o smysl,” in Spor o smysl českých dějin 1895-1938, 10 -24. 
sives, including borderline anti-Semitic attacks on "Mosaic clericalism"; Protestants - especially members of the reformed church - still saw themselves as the one and only truly Czech denomination; and, apart from their virulent anticlericalism, most progressives were unconcerned with questions of religion and felt satisfied with a vague need for a cultural renaissance. ${ }^{27}$

A succession of events that took place between 1897 and 1904, however, changed everything. In this period, progressive liberal thought was linked with religion, creating a movement, which - although small in numbers - catered specifically to religious minorities and proved influential. Additionally, a progressive framework and its proponents became dominant within each religious community, transcending traditional notions of institutionalized religion.

\section{The Hilsner Affair and the Emergence of a Progressive Czech-Jewish Movement}

The first event that rattled traditional political allegiances was the Hilsner affair of 1899. Since the early 1890s, the public mood in Bohemia was prone to anti-Semitic outbursts. Following a broad campaign of nationalists for Czechs to patronize Czech businesses (svi̊j $k$ svému), Jewish businesses were targeted for public violence. The situation in Prague was especially volatile, as the city had become the focal point of the Czech-German conflict. Already early in 1897, the Young Czech Party had fielded an openly anti-Semitic candidate for the upcoming elections to the chamber of deputies, hoping to absorb the expanded electorate. ${ }^{28}$ As a consequence of the introduction and subsequent retraction of the language ordinances by the Badeni government in 1897, first Germans, and then Czechs in Prague had rioted. Jewish businesses and buildings bore the brunt of these assaults. ${ }^{29}$

The peak of this anti-Semitic wave was probably the well-known Hilsner affair, which marked a turning point in the relations of Czech Jews and the Czech national movement. ${ }^{30}$ In 1899, after a young girl was found dead in the East Bo-

27 Under the manifest of "Česká moderna” (Czech modernity), several influential writers of the young generation had decried the lack of culture in the Czech liberal establishment.

28 Hillel Kieval, "Nationalism and Antisemitism," 216-7. There are, of course, obvious parallels to the rise of Karl Lueger (1844-1910) in Vienna.

29 Kateřina Čapková and Michal Frankl, "Diskussionen über die 'Judenfrage' in den böhmischen Ländern,” 224-7.

30 To put it into context, already at the time there was talk of it as the "Austrian Dreyfus affair," with several obvious parallels in how both cases were being treated in the public. As T. G. Ma- 
hemian town of Polná, the local authorities arrested a Jewish vagabond, Leopold Hilsner, and accused him of murdering her in line with Jewish rituals. Accusations of ritual murder were still quite common in the region, particularly in rural Catholic areas. What made the Hilsner case special was that the authorities seemed to endorse the blood libel. ${ }^{31}$ Subsequently, the whole trial became an anti-Semitic showcase, with not only Hilsner but all Jews on trial, as it were. ${ }^{32}$ One of Hilsner's few public defenders was a Czech university professor named Tomáš Garrigue Masaryk, who was a well-known public intellectual and supporter of the progressive cause. He intervened after Hilsner was already convicted of the murder, but accomplished the reopening of the case mainly by attacking the idea of ritual murder as scientifically absurd. ${ }^{33}$

As the Young Czech Party showed no sign of reining in its more anti-Semitic members or condemning the affair, the Czecho-Jewish assimilationist movement was thrown into crisis. After its main newspaper, the Českožidovské listy, continued to support the nationalist movement even in the face of the latter's support of anti-Semitic tendencies, a group of young Czech Jewish intellectuals, led by Eduard Lederer (1855-1944), Viktor Vohryzek (1864-1918), and Bohdan Klineberger (1859-1928), broke away. The breakaway group called itself “Rozvoj” (Advancement) and published a journal of the same name. ${ }^{34}$ Based in the Bohemian town of Pardubice, Rozvoj still advocated Czech-Jewish assimilation, but reconfigured it by speaking of the acculturation of a separate Jewish identity within a national framework..$^{35}$ It also pointed to the need for new and more modern political allies: Czech liberals had betrayed the teachings of Hus and abandoned the path to enlightenment that these teachings had provided. The solution was the strengthening of progressivism: anti-Semitism, after all, was essentially

saryk, one of the main protagonists of the affair, noted, it had an international impact that none of the participants foresaw. For a detailed reconstruction as well as the historical context of the affair, see the articles in Miloš Pojar, ed., Hilsnerova aféra a česká společnost 1899-1999. Sborník přednášek z konference na Univerzitě Karlově v Praze ve dnech 24.-26. listopadu 1999 (Prague: Židovské muzeum v Praze, 1999).

31 As Kovtun points out, such cases did show up in court periodically but were usually rejected by the authorities. Jiři Kovtun, "Historická dimenze Hilsnerova případu," in Pojar, ed., Hilsnerova aféra a česká společnost 1899-1999, 17-23, esp. 17-8.

32 Without further proof it was assumed that Hilsner had been helped by two - supposedly Jewish - accomplices, strengthening the anti-Semitic nature of the case.

33 Tomáš G. Masaryk, Nutnost revidovati process Polenský (Prague: Casu, 1899). Masaryk went so far as to actually take some lessons in anatomy, travelling anonymously to Vienna.

34 Vondrášková, "The Czech-Jewish Assimilation Movement and its Reflection of Czech National Traditions,” 151-2.

35 Weiglová, "Barometer," 94-5. 
a religious problem, born of reactionary clericalism. ${ }^{36}$ As Vohryzek argued in the inaugural edition of the Rozvoj journal, the key to assimilation (or rather, acculturation) for Czech Jews was religion. ${ }^{37}$

\section{The "Realist" Party as a Religious-political Project and its Protestant Supporters}

Masaryk's defense of Hilsner made him an outcast in most nationalist circles. Apart from the Czech-Jewish movement, only the socialists and a small but determined group of loyalists stood by his side. With the Hilsner affair still in full swing in the spring of 1900, Masaryk and his followers founded yet another progressive party under the name "Česká strana lidová” (Czech People’s Party), known as "Realists." Although plans for such a party had existed for some years, its founding was inevitably tied to the Hilsner case. ${ }^{38}$ Masaryk's prominence in the affair and his leading role in the Realist party earned them the anti-Semitic moniker "the Hilsner Party" among the nationalist press. This was at least true insofar as the progressive Rozvoj group enthusiastically welcomed its arrival. ${ }^{39}$

The Hilsner affair, however, tends to overshadow two other important factors in the founding of the party. There was a distinct Protestant influence present, with progressive Protestant clergy such as the Calvinist Čeněk Dušek (18431918) and the Lutheran Ferdinand Hrejsa (1867-1953) instrumental in its inauguration. ${ }^{40}$ Several leading members of the Realist party, such as Jan Herben (1857-

36 Kieval, Languages of Community, 168-75.

37 Viktor Vohryzek, “Několik slov úvodem," Rozvoj: Týdenník českých pokrokových židů 1:1 (1904): $1-3$.

38 Johannes Gleixner, "Menschheitsreligionen”: T. G. Masaryk, A. V. Lunačarskij und die religiöse Herausforderung revolutionärer Staaten (Göttingen: Vandenhoeck \& Ruprecht, 2016), $79-86$.

39 One of the founding fathers of the Czech national movement, František Ladislav Rieger (1818-1903) referred to the Realist party as a Jewish, and therefore destructive, party; see Roland J. Hoffmann, T. G. Masaryk und die tschechische Frage, Veröffentlichungen des Collegium Carolinum 58 (Munich: Oldenbourg, 1988), 221-2, here at 239; Kieval, Languages of Community, $198-203$.

40 "The Realists lean towards Protestantism" commented the independent progressive journal Osvěta lidu. "České "Pryč od Říma”?," Osvěta lidu: Pokrokové noviny pro severovýchodní a východní Čechy 6, no. 94 (1901): 4; See also Hoffmann, T. G., 262. 
1936), Žilka, and Masaryk himself, were known to be members of the reformed church. ${ }^{41}$

The party presented an elaborate program which stood out in one main respect: it stressed the need for a unifying, encompassing religious reform that would overcome existing traditional beliefs not only in a scientific but also more moral way. While the program conceded that the party had a certain affinity to the progressive movement and Protestantism, it pointed emphatically to the failure of all positive religions and denominations. Catholicism, Protestantism, and Judaism were all full of "halfness" (polovičatost), unfit for modern society. Even more interesting, although the program stressed the religious freedom of the individual, it paradoxically demanded a kind of modern religious politics. ${ }^{42}$ Masaryk, who wrote the program himself, had expanded on these ideas in a series of programmatic books published during the 1890s. They all came down to an interpretation of Czech history as an attempt to live according to "humanist" principles. The embodiment of those principles was the Czech reformation; as such, the Czech question was not only one of language, culture, and political power, but at its heart religious in nature. Czechs, then, should strive to become religiously enlightened. Masaryk's notion of Hus and the reformation was ahistorical and universal..$^{43}$ Nonetheless, he claimed to have distilled the scientific core of modern religion. He demanded a Czech version of the "Los von Rom" (Away from Rome) movement, which saw some success in Germanspeaking areas of Bohemia, insisting that the new church must be religious, albeit not identical to the existing Protestant churches. ${ }^{44}$ This paradoxical demand makes sense if it is understood as an attempt to craft a new majority discourse based on religious convictions without referring to existing denominations and religions.

At first, the Realists were a loose collection of groups preoccupied with progressive religious and cultural topics. Apart from the party founders, intellectuals from Prague, this included progressive Jews and Protestants but also Free

41 Many of them, Masaryk included, left the Catholic church and joined the reformed church. This was a political statement as much as it was a religious one.

42 Rámcový program české strany lidové (realistické) (Prague: Nákladem výkonného výboru české strany lidové, 1900), 77-9.

43 See, among other sources: Tomáš G. Masaryk, Jan Hus. Naše obrození a naše reformace (Prague: Cas, 1896).

44 See Tomáš G. Masaryk, Ideály humanitní a texty z let 1901-1903, Spisy T. G. Masaryka 25 (Prague: Masarykův ústav a Archiv Akademie věd ČR, 2011), 191. This was a curious demand, as conversions to the Lutheran church were precisely the point of the pan-German "Los von Rom.” 
Thinkers and Atheists. Emanuel Chalupný (1879-1958), a founding member of the party and later its sharp critic, noted how it consisted of three groups, each one of which viewed the party as a vessel of its specific ideas: Protestants, Jews, and “original” Realists with a cultural interest in progress. For Chalupný, the party lacked any consistent ideology, and was united only in mutual interest and an almost religious belief in its own notion of progress. ${ }^{45}$ Although his perception of the party's most important wings was accurate, Chalupný was nonetheless motivated by a strong anti-Protestant bias, and underestimated the religious content of the party's program. Early on, Protestant Realists tried to push for an official allegiance to the reformed church, arguing that being a reformed Protestant was the closest one could come to a synthesis of religion and progress in the absence of a true future religion. ${ }^{46}$ Echoing the party's program, one Realist argued that simple political parties could not succeed in modern times. Only movements with an "ideal" (like Social Democracy) had a future. The Realist party, then, should work as an avant-garde movement to the "Protestantization" (poprotestantštění) of the people. ${ }^{47}$ Other Protestant Realists opined that party members should at least leave the Catholic church if not outright join one of the Protestant denominations. This idea clashed not only with the Jewish Realists but also with those close to the Czech Free Thought (Volná myšlenka), such as Chalupný, who favored the legal status of "without confession" as most closely approximating religious enlightenment. ${ }^{48}$ In turn, Lederer, one of the leading Jewish Realists, pointed out that he and other progressive Jews were perfectly content with conversion to a truly progressive religion, but so should be the Protestants, as their belief was similarly unfit to capture the religious spirit of the Czech nation. ${ }^{49}$ In this remark, Lederer rehearsed the charge

45 Emanuel Chalupný, Vzník české strany pokrokové. Historické vzpomínky. Dle původních pramenů (Tábor: St. D. Kubíček, 1911); Zlváštní otisk z "Českého Jihu” 1-2; 54-5.

46 See František Žilka, “Z vývoje a výsledků moderní vědy bohoslovecké,” Naše Doba 9 (1902): 349-50.

47 "Postavení strany čes. lidové v politické organisací národní (z kruhu rádců české strany lidové)," Přehled 1:21 (1902): $336-7$.

48 “O organisaci české strany lidové (Schůze politického klubu 29. dubna),” Přehled 1:22 (1902): $367-77$.

49 Eduard Lederer, “Die čechisch-jüdische Assimilation,” Čechische Revue 2 (1908): 404-7. Both Lederer and Vohryzek went so far as to put Judaism above the Christian creeds in the ranking of progressive beliefs. See also Vohryzek, "Několik slov úvodem”: 2; Interestingly, conversions from Judaism to Protestantism were apparently much more common in Austria (especially Vienna) than in the Czech lands. See Astrid Schweighofer, Religiöse Sucher in der Moderne: Konversionen vom Judentum zum Protestantismus in Wien um 1900, Arbeiten zur Kirchengeschichte 126 (Berlin, Munich, and Boston: de Gruyter, 2015), 64-74. 
made by other progressives who complained about the Protestant goal of transforming every belief but their own..$^{50}$

\section{The Hus Affair of 1903: Protestants as National Outcasts}

The year 1903 witnessed the Protestants' own excommunication from the Czech nation, thwarting their self-perception as an avant-garde of Czechness. Being part of an integrative narrative of progress was not the same as dictating it, as the Czech Jews were all too aware. The Protestants, however, had to learn this lesson the hard way by squaring off against the majority discourse of Czech nationalism, which so far had paraded them as progressive paragons of the antiCatholic nation.

When, on 6 July 1903, the foundation stone of a long-planned statue of Jan Hus on Prague's Old Town square was laid, a Young Czech speaker celebrating the occasion tried to affiliate the Hussite tradition with Catholicism. The statue of Hus was being erected right across the Marian column, the symbol of Catholic reign in Prague - a fact that in his view signaled a mutual belonging. Both the Protestant press and the Realists responded with fury, claiming that the Young Czechs had abused the Czech reformation and made a political pawn out of its martyr. A simultaneous celebration of Realists and leading Protestants was lauded as the true embodiment of the spirit of Jan Hus. ${ }^{51}$

Six days later the nationalist press struck back, remarking on the proximity of the Realists to the "Los von Rom," a pan-German Protestant movement led by German nationalists and advocating a greater German empire. "Národní listy," the main organ of the Young Czech Party, attacked the Realists as traitors to the national cause. Although the charge itself was ridiculous, Masaryk and especially Dušek had been in close contact with German Protestants from organizations like the "International Committee for the Evangelization of the Bohemian Lands," owing to their prioritization of religious cooperation over national conflict. ${ }^{52}$ When a leading Realist Protestant, Jan Herben, was seen entering the German "casino" in Prague to meet with a German Protestant activist, the nationalists finally found him caught in the act: behind the Realists' "religiousness," they

50 Gustav Tichý: "Etická kultura, náboženství a mravnost,” Rozhledy 14 (1904): 966-9.

51 Čas, "Husovy oslavy,", July 8, 1903.

52 Lothar Albertin, "Nationalismus und Protestantismus in der österreichischen Los-von-RomBewegung um 1900” (Diss. Phil. University of Cologne: 1953), 123-51. 
alleged, was a plot to lure the Czechs to German Protestantism. Gleefully, they pointed to the hypocrisy of criticizing the Young Czechs' political efforts to compromise with Catholic parties but at the same time embracing a pan-German Protestant plot to subvert the monarchy. ${ }^{53}$

Anti-Protestantism further fueled the already-raging anti-Semitic blaze ignited by several Catholic nationalist authors. In one striking example, the writer Rudolf Vrba (1860 - 1939) linked the Protestant "Away from Rome" to an international Jewish plot and saw Austria besieged by both German-Protestant infiltrators and Jewish intellectuals. ${ }^{54}$ In the eyes of the Catholic-nationalist consensus, Protestants and Jews alike were excluded from the true Czech nation, although both groups - and especially the progressive Czech-Jewish movement - were clearly working against the Germanization of their communities. Still, the image of Jews as an avant-garde of Germanness in the Bohemian lands, dating back to the middle of the century, persisted. Vrba's exploitation of prejudices against supposedly foreign agents who sought to undermine the Czech nation from within is an interesting example of the fluidity of anti-Semitic stereotypes, with Protestants joining Jews as national traitors.

Although Herben defended himself, the damage was already done and the Realist party struggled to distance itself from the perception of being the political arm of the Protestant churches. An official declaration by the executive committee proclaimed a Czech "Away from Rome" with no association to any existing church. Furthermore, the party stressed its independence from any religion. It repeated its programmatic hostility to any form of "clericalism," explicitly including Protestant, Jewish, and even Orthodox types. ${ }^{55}$ This official distancing from organized religions belies its internal discussions, in which the Protestant's overidentification with the party constituted the main problem.

\section{A Political Coalition of Religious Dissent}

It came down to Masaryk to settle questions of ideology, as no other Realist matched his authority. Already in 1901, Masaryk seemed keenly aware of the Realist party's position as a political beacon for incompatible religious dissent: when a Protestant supporter complained that the party's official paper, Čas, was too "Philo-semitic" and not Protestant enough, Masaryk replied that indeed

53 Hoffmann, T. G. Masaryk, 253-5.

54 Rudolf Vrba, Österreichs Bedränger: Die Los-von-Rom-Bewegung. Studien über politische, religiöse und sociale Zustände der Gegenwart (Prague: Selbstverlag, 1903), 632.

55 “Řím a Berlin,” Přehled 1:33 (1902-1903): 533-6. 
it was sometimes unbalanced in its polemics, but more importantly, it was the only place in the Bohemian lands where one could talk seriously about religion. Slyly, he added that for Protestants there was no other political newspaper anyway. Even more interestingly, he pointed to the main editor of Čas, Herben, a known Protestant Realist, as proof of the paper's religious sincerity, while simultaneously distancing his own conviction from that of Herben. ${ }^{56}$

As the annual Hus celebrations of 1904 approached, Masaryk felt the need to clarify the party's position on religion, lest there be another scandal. Expanding on the paradoxical formula of religion being a private matter but not an individual one, he delivered a speech at a gathering of the Realists' political club (its de facto executive committee) on 25 April 1904. In it, he stressed the demand for political freedom as fundamental to the Realist program. Further explaining his own conviction, he affirmed the need for religion, but for the first time openly denied the scientific possibility of Christian revelation. ${ }^{57}$ This speech was received with marked ambivalence: while a younger group of activists with a decidedly atheist stance was unsatisfied that Masaryk did not outright advocate atheism, ${ }^{58}$ the 'religious' Realists seized the moment to fuse the party's vague religious-political program with their own goals, thus completing the party's transformation into a political conduit for religious dissent. Overall, they expressed relief that Masaryk had finally spoken openly on these issues, even if his denunciation of biblical revelation was in no way acceptable to believers. ${ }^{59}$

Interestingly, while the whole Hus affair placed into question the RealistProtestant alliance, in the long run, the pact was strengthened. Protestants such as Dušek had long realized that Masaryk's inchoate religious convictions were not actually Protestant. Masaryk himself was at times highly critical of Protestantism, once claiming to feel emotionally more like a Catholic. ${ }^{60}$ Dušek and other Protestants clergymen sharply disagreed with him from a theological point of view, while stressing that the Realist party remained the only political possibility for Protestants - the culturally "Catholic" Young Czechs and their shallow anti-clericalism were hardly an option. ${ }^{61}$ As one progressive (and later

56 AÚTGM (Archive of the Masaryk institute Prague), fond TGM Kor I, kr. 29, 1. 44.

57 Čas, "Pro svobodu svědomí,” June 26, 1904.

58 Hoffmann, T. G. Masaryk, 261-2.

59 Čas, "Pro svobodu svědomí”.

60 See Čas, "Prof. Masaryk v Katolických listech,” January 30, 1902. Masaryk was born into a devout Catholic family.

61 Matějka, “Čeští luteráni 1861-1918,” 283. 
Realist) paper commented, the affair led to the "full emancipation of the Czech Protestants from the Young Czechs."62

For the progressive Czech Jews, Viktor Vohryzek commented on the speech: he, too, claimed relief that the party's leader had finally spoken up on the "religious question." Although he conceded that Masaryk still had not provided the "promised religious-philosophical thesis, the basis of a new and pure religion, scientifically worked out and reasoned," he nevertheless was optimistic about the matter. In his view, by stripping existing religion of its non-scientific, nonmodern elements, the religious progressives of each denomination, and with them even monists and atheists, would end up together.

Additionally, Vohryzek rightly observed the split between an agnostic notion of progress, which was content to criticize the church and religion in general, and the "truly progressive" Realists, who went beyond simple negativity and for whom traditional beliefs like Christianity and Judaism remained historical, if flawed, vessels of true religiosity. To drive home his point, Vohryzek approvingly quoted the evangelical "Hlasy ze Siona" (Voices from Zion) that a future religion still had to include some kind of formal confession (konfesse). To be (in a strictly legal sense) "without confession," therefore, was no indication of positive progressiveness; one had to think and act in its spirit as well. And, turning the tables on Protestants and atheists alike, he noted that Judaism, with its lack of clerical structures and its everyday adherence to moral laws, was already very close to such a religion of the future. For progressives like him, "Mosaism" was neither a belief nor a confession in the accepted sense. "We will defend our Realism against old denominations and new ones, if they are not in agreement with it," he finished. ${ }^{63}$

In this respect, progressive Czech Jews were closer to the core of the Realist movement than many Czech Protestants. Like Masaryk and his disciples, and despite stressing a "positive" spirituality, figures such as Lederer and Vohryzek displayed an intellectual and utilitarian understanding of religion. As Hillel Kieval notes, their pronounced "anti-secularism" came with a distinctly casual attitude toward actual religious practice. ${ }^{64}$ This was true for some Realist Protestant intellectuals like Herben as well. In contrast, it was mostly clergymen, like Hrejsa and Dušek, who promoted progressive and political Protestantism. As such, these Protestants had a more ambivalent relationship with the Realists, grasping the need for this cooperation but aware that the religious-political vision of the

62 Hoffmann, T. G. Masaryk, 258.

63 Viktor Vohryzek, “O svobodě náboženské a volnosti přesvědčení,” Rozvoj: Týdenník českých pokrokových židů 1:27 (1904): 1-2.

64 Kieval, Languages of Community, 174. 
Realists did not necessarily align with their own vision of a unified Czech Protestant church. Moreover, the progressive wing of the Czech-Jewish movement could not claim to represent the majority of Jews in the Bohemian lands, while the combined Protestant churches' membership did indeed form a majority of Czech Protestants.

In the end, just as Vohryzek observed, those who split from the party were Free Thinkers and atheists such as Chalupný and other so-called "Young Realists," centered around the journal Přehled, who were disappointed that religious influences remained strong. Other progressives attacked both the Realists and the Protestants for their purportedly unfounded alliance. ${ }^{65}$ Unsatisfied with Masaryk's eternally obscure answers, they demanded to know the specifics of the Realist program of a future religion.

\section{A Future Religion as an Inclusive and Transformative Political Program: Jews and a United Protestantism as Standard-bearers of "Hussitism"}

It is worth taking a closer look at why the Realist party program, in all its opacity, was so attractive to religious dissent. The peculiar insistence that societal problems stemmed from religious ones seemed out of place in the other progressive parties, most of which were content with aggressive anticlericalism. However, in maintaining that while existing denominations and religious beliefs were flawed, religion itself was not, the Realists extended an irresistible offer to religious minorities to become part of a new religious whole. To frame the Czech question in terms of modern man and religion, as Masaryk did, offered a new option of joining the nation by transforming it. This contrasted with his quite exclusive vision of the nation, as expressed in an interview with Rozvoj, where he declared that the Jews' religious identity was an obstacle in them becoming Czechs. ${ }^{66}$ It ought to be borne in mind, however, that the most salient feature of Masaryk's and the Realists' vision of the nation was its exclusion of average

65 See Karel J. Rohan, “Moderní stoupenci Husovi,” Rozhledy. Revue umělecká, sociální a politická 14 (1903-1904): 1-7; 31-40; 59-66.

66 See Michael A. Riff, “The Ambiguity of Masaryk's Attitudes on the 'Jewish Question',” in T. G. Masaryk (1850 -1937), vol. 2; Thinker and Critic, ed. Robert B. Pynsent, Studies in Russia and East Europe (Basingstoke: Macmillan, 1989): $77-87$, here at 83. 
Czechs and even the reformed church, thus levelling the playing field for all. As Masaryk himself said, the Realists were not a party of the masses and could never become one; nonetheless, they served as an avant-garde to the whole nation. ${ }^{67}$

At the same time, the fusion of religious convictions with political action allowed the progressive wings of Czech Protestantism and Judaism to surmount traditional institutions, if for conflicting reasons. Progressive Czech Jews and Protestants agreed that the battle for a renewed religiosity was not being fought in the churches and synagogues, but in the political arena. Both felt - albeit for different reasons - the need to overcome institutionalized religion.

The leaders of the Protestant churches, Dušek and Hrejsa, understood that their vision of a unified church which called for the fusion of existing communities did not go far enough. As they aspired to become a true Czech church, they needed to address the non-Protestant masses. The Protestantization of the Czechs would happen, in their view, not through preaching but through political action. Unified Czech Protestantism, then, was at its core a political project that required a political entity. The appeal of the Realists in turning people away from old beliefs and towards a more modern religion seemed to suit the bill.

Similarly, progressive Czech Jews perceived the politicizing of modern religion as a means for Jews to integrate into mainstream society on their own terms. For Vohryzek, it was the Czechs who had strayed from their national ideals of progress as embodied by people like Hus and Comenius. The Christian Czechs needed their Jewish brethren to complete the journey to their true national character. To reach this stage, a Czech-Jewish accommodation was inevitable. ${ }^{68}$ Masaryk seemed to accept this conflation of the historical meaning of the Czech reformation and a Czech-Jewish path towards it. As he wrote Vohryzek, he was particularly pleased to see the progressive Czech Jews propagating the reform movement. ${ }^{69}$

This unique vision of the progressive meaning of the Czech reformation therefore managed to include a progressive Judaism not by accepting Jews as they were but by escalating its demands for Jews and Czechs alike. As Vohryzek and other progressive Jews recognized, the hazy notion of a true Czech reformation could be expressed in terms that conveyed equidistance between Jewish and Protestant (or for that matter, Catholic and Free Thinking) visions of a future re-

67 Česká stráž. Lidové noviny pokrokové, “Z táboru české strany lidové” January 20, 1906, 3. 68 Vohryzek, "Několik slov úvodem," 3.

69 The Czech term "reformní hnutî" conveys the semantic appeal to the protestant reformation much stronger. See Tomáš G. Masaryk, “Dopis v redakci,” Rozvoj: Týdenník českých pokrokových židů 1:1 (1904): 3. 
ligion. Consequently, the Czech-Jewish position went from being indebted to the benevolent and tolerant Czech nation ${ }^{70}$ to guiding the very same nation back to its lost ideals. ${ }^{71}$

Last, the notion of a religious avant-garde was a reaction to societal changes. When the rise of political Catholicism threatened to marginalize non-Catholics, the idea that the fundamental social transformation was just the cusp of a fundamental spiritual transformation was particularly attractive to projections of future majorities. Commenting on political Catholicism, Bohdan Klineberger noted, "A change in the war tactics [of the Catholic church, J.G.] has happened. [It points, J.G.] into politics: the abstract fight is cast aside, the fight for political power is happening." And he continued, "The political fight has priority over the scientific. While this uses arguments and reason, that uses feelings and power." 72

Klineberger here used an argument endorsed by atheist Free Thinkers. This argument exposed how the politicization of progressive religiosity served as an integrating moment for a loose coalition of progressive subgroups. Theological differences aside, they had a common enemy: clericalism, which held the Czech nation back, whether by fomenting anti-Semitism or promoting general backwardness. A strong turnout of Catholic voters was expected in the upcoming elections, thus making the political battle for the spirit of the Czech nation a real one indeed. Klineberger also formulated a central insight: the struggle for a new scientific religion was always a political one, if it was to be more than a mere intellectual exercise. Liberalism, for Klineberger, had done more than overlook the real economic damage people in rural areas had experienced: its proponents had neglected to notice how this damage provoked anti-Semitism, particularly among small rural businesses. An anti-liberal movement had arisen by addressing this common feeling of being left behind, and from this common feeling a common ideology followed. Such an anti-liberal party, perforce, had to be an anti-Semitic one as well. It was the Christian Social and Catholic peoples' parties that united these voices and imbued them meaning.

Klineberger made a crucial point: the rural masses, which supported the (anti-Semitic) Catholic parties, sided with these parties because of concrete

70 Vondrášková, "The Czech-Jewish Assimilation Movement and its Reflection of Czech National Traditions,” 154.

71 Kieval, Languages of Community, 171.

72 Bohdan Klineberger, “Otázka antisemitismu," Českožidovské listy 7:2 (1901): 1-5, here at 2-3. 
changes in the structure of society. ${ }^{73}$ The question of who would represent the majority of the Czechs in the future was, therefore, still an open one.

\section{Political Success and Demise}

When, in 1906, the Realist party merged with another Progressive splinter group to form the "Česká strana pokrokovâ" (Czech Progressive Party), the policy of religious progressivism reached its zenith. This time round, the Protestant party members had learned their lesson: several speakers stressed that the reactionary wave (i.e., the political successes of Catholic parties) could only be abated by the progressive elements making common cause. The party's press also spotlighted the mistakes of the Young Czech Party, which had ignored religion as a central topic of contemporary politics. ${ }^{74}$ In the 1907 elections to the Vienna chamber of deputies, the party was remarkably successful, given that it represented only a tiny minority of voters. It managed to get two deputies, František Drtina and Masaryk himself, elected. Drtina, however, was elected by a coalition that included Catholic parties. It was mainly Masaryk, the charismatic leader of the Realists, who successfully campaigned on a religious program and managed to defeat his Catholic opponent in his East Moravian voting district. This put an end to the longstanding campaign against the Catholic church that the party had waged almost from its inception. Once elected, Masaryk's attempts to debate religion in politics fell flat. His critique of the Catholic church led once again to an alliance with the pan-German nationalists, which he then quickly abandoned.

Already before the war, during the next elections in 1911, the Realists drifted back into mainstream liberalism. An alliance of progressive forces seemed to be a political necessity, thus reducing the importance of religious topics. During the war, the remaining leadership of the party surrounding Herben joined forces with the other bourgeois parties to form a single nationalist block, overlooking the virulent anti-Semitism of several of its proponents. In protest, Lederer left the party, which subsequently split up, disappearing shortly after the end of the war. $^{75}$

73 Ibid., 4-5.

74 Česká stráž. Lidové noviny pokrokové, January 27, 1906.

75 For Lederer's reaction, see AÚTGM, f. TGM, Republika, Židé, kr. 453. On the final demise of the party, see Josef Harna and Martin Kučera, eds., Politické programy českých "pokrokových" stran 1896-1900, Edice politických programů 6 (Prague: Historický ústav, 2010), 22-4. 


\section{Conclusion}

The present chapter makes the claim for a simultaneous change in discourses about nation and religion on the one hand, and the structural conditions of the national public on the other. As the focus of Czech politics shifted away from the center and the bourgeois milieu to the smaller towns and their specific socio-cultural environment, its integrative framework changed as well. Although the Bohemian towns had long featured in national mythology as the preservers of Czech culture, it was the actual expansion of the voting franchise that placed them in the midst of a battle for the mobilization of a majority. The Czech-German conflict receded into the background of these debates. The question of who among the Czech speakers was also Czech in a spiritual way became more and more prominent. Not only did the liberal nationalists abandon their tolerant vision in order to woo the Catholic population, but the minority positions also changed. The new direction of the Czech-Jewish assimilation movement, then, was not only a reaction to the anti-Semitic wave of the 1890s. In the Czech context, religiosity became political, as the question of what it meant to be Czech seemed to spark an increasingly diverse range of answers. Masaryk and his followers openly advocated a religious and spiritual reawakening of the nation, something that neither Catholic nor secular nationalists had ever done. The main fault line had been moved from between political Catholicism and the anti-clerical national movement to one between a "religious" and a "non-religious" vision for society. And curiously, the "clerical" parties fell into the latter camp, at least from the perspective of the religious progressives.

Comparison of the Jewish and Protestant positions reveals how both communities were part of a larger shift in Czech society. The motivating factor was the changing national discourse, which had to address a larger public by becoming narrower and more exclusive. Moreover, it was oftentimes unclear who would represent the rural masses that had now entered politics. In this way, religious communities came to see their own identities as increasingly tied to the political discourse, prompting the idea of a political and spiritual awakening within Czech society. They countered the apparent new consensus with an integrative vision of their own, addressing - at least in theory - a different national collective themselves. Even if their vision was narrower from a socio-cultural point of view, it still offered an interesting and alternative discourse that stressed the religious nature of Czechness in order to make it more inclusive. While, by definition, this national religion of the future had to remain indeterminate, it nonetheless displayed political power. To a certain extent, it was a transitional phenomenon on the road to modernity, responding to the question of nationality 
but also to that of collective identity in modern times. ${ }^{76}$ When the (male) mass public finally broke free from restrictions in 1907, this alternative could claim a place for itself. And when the Czechoslovak republic came into existence in 1918, this religious vision loomed large in the republican raison d'être.

Within a small window of opportunity, all these shifts could be brought together by a unifying vision of a progressive religious future. While its immediate political impact was ultimately negligible, it did provide a framework for Czech national discourse that reappeared after the war, again presenting the Czech reformation as a prism of Czech universality.

76 With regard to Germany, one should mention Thomas Nipperdey’s famous term "vagrating religiosity." 
